\title{
Development of Suitable IDM Approaches for Management of Fusarium Wilt of Tomato [Fusarium oxysporum f.sp. lycopersici (Sacc.) Synder and Hansen] under Climate Change
}

\author{
Vallabhaneni Tilak Chowdary*, S.K. Biswas, Deepak Baboo and Sumit Kumar \\ Department of Plant Pathology, CSA University of Agriculture \& Technology, \\ Kanpur - 208002, India \\ *Corresponding author
}

\begin{abstract}
A B S T R A C T
Integration of different methods for suitable management of Fusarium wilt revealed that the minimum disease severity was found in case of soil application with Mushroom spent + combined seedling treatment with T. harzianum, Azotobacter and Rhizobium + first foliar application with Benfil (Carbendazim) + second foliar application with Matco

\begin{tabular}{|c|}
\hline Keywords \\
\hline $\begin{array}{l}\text { Fusarium wilt, } \\
\text { IDM, Bio agents, } \\
\text { Bio-fertiliser and } \\
\text { Fungicides }\end{array}$ \\
\hline Article Info \\
\hline $\begin{array}{l}\text { Accepted: } \\
15 \text { October } 2018 \\
\text { Available Online: } \\
10 \text { November } 2018\end{array}$ \\
\hline
\end{tabular}
(Metalaxyl + Mancozeb), representing the value $6.50 \%$ as against 54.65 per cent in case of control. Growth promoting effect of plants has also been noticed due to application of IDM practices. The maximum shoot length and root length was observed in the treatment of soil application with Mushroom spent + combined seedling treatment with T. harzianum, Azotobacter and Rhizobium + first foliar application with Benfil (Carbendazim) + second foliar application withMatco (Metalaxyl + Mancozeb) representing the values $45.50 \mathrm{~cm}$ and $37.00 \mathrm{~cm}$, respectively at 45 DAT against $29.50 \mathrm{~cm}$ and $10.15 \mathrm{~cm}$ in case of control and $23.40 \mathrm{~cm}$ and $8.50 \mathrm{~cm}$ in case of control 2 . Fresh and dry weights of the shoots were also found maximum in the same treatment, representing the values $66.50 \mathrm{gm}$ and $21.50 \mathrm{gm}$, respectively. Similar observations have also been recorded in case of fresh and dry weights of roots with the values $36.50 \mathrm{gm}$ and $12.30 \mathrm{gm}$, respectively. Maximum number of branches and flowers/plant were also found in the $T_{7}$ treatment where soil application with Mushroom spent + combined seedling treatment with $T$. harzianum, Azotobacter and Rhizobium + first foliar application with Benfil (Carbendazim) + Second foliar application with Matco (Metalaxyl +Mancozeb) showing 13.60 branches/plant and 90.60 flowers/plant where in case of control-1 the values are 5.80 and 50.90 and control-2 values are 3.60 and 16.40. The maximum yield with $1.703 \mathrm{~kg} /$ plant was also obtained from the same treatment.
\end{abstract}

\section{Introduction}

Tomato (Lycopersicon esculentum Mill.) is considered as one of the most important and remunerative vegetable crops cultivated throughout the world owing to its high nutritive values as well as its antioxidant and curative properties. It is a major contributor to the fruits and vegetables diet of humans throughout the world (Kapasiya et al., 2015). Tomato is susceptible to several diseases like damping off, early blight, late blight, Fusarium wilt, verticillium wilt, bacterial wilt, tomato mosaic virus etc. Among them, 
Fusarium wilt caused by Fusarium oxyporium f.sp. lycopersici (Sacc.) Snyder and Hansen is an economically important disease of tomato crop worldwide (Beckman, 1987; Hanaa et al., 2011). The disease is responsible to cause severe losses ranges from 3.58-20.63\% (Sharma et al., 1985). The pathogen is polyphagous in nature and has wide adaptability under climate changes (Singh, 2014; Gill et al., 2016, Bhupendra et al., 2017). Therefore management of the disease is very difficult and single method is not sufficient for management of the disease. Mukhopadhyay (1987) found an integrated approach of using cultural measures, biological control, chemical control for management of the Disease. Narender and Sharma (2015) found that bio fumigation of affected soil for 30 days with taramira crop residues, application of formulation of $T$. viride after mixing with FYM and inoculation of transplants with culture consortia of indigenous AM fungi resulted in to controlling the Fusarium wilt. An Integrated approach using Carbendazim, $T$. viride along with Neem seed kernel extract resulted in reduction of wilt incidence caused by Fusarium oxysporum against cumin (Bhatnagar et al., 2013). Minuto et al., (2000) reported that the combination of soil solarization with reduced dosage of Dazomet and methylbromide controls Fusarium and Verticillium wilts in tomato. Under field conditions, the combination of $T$. harzianum with soil solarization or with a reduced dose of methyl bromide resulted in significant disease control of Fusarium wilt (Sivan and Chet, 1993). Combination of the biocontrol agent $P$. fluorescens with the mineral element zinc significantly reduced disease severity of Fusarium wilt of tomato (Duffy and Defago, 1997). Considering the above point's in view current research was done to develop integrated disease management strategies against Fusarium oxyporium f.sp. lycopersici in Tomato.

\section{Materials and Methods}

\section{Isolations of pathogen}

The diseased plant showing typical wilt symptom was used for isolation of the pathogen. The diseased plant's roots were taken and washed thoroughly with tap water and finely with distilled water to remove all dust particles. The diseased part of the root is cut into small pieces by sterilized blade in such a way that each piece had small bits of diseased and healthy parts. The chopped pieces were dipped in mercuric chloride solution $(0.1 \%)$ for 30 seconds rinsed in sterilized distilled water thrice and dried off with sterilized filter paper. The small pieces were then placed on PDA based media which was previously pour in sterilized Petri plates. The plates were finally sealed with paraffin tape and were incubated at $25 \pm 1^{0} \mathrm{C}$. The Petri plates were observed daily to find out the presence of mycelium around the bits. As soon as mycelia growth is notices around the bits, the pathogen was purified by hyphal tip culture method.

\section{Collection of Bio - fertilizers}

Bio-fertilizers viz., Rhizobium and Azotobacter were collected from Department of Soil Science and Agriculture Chemistry, Chandra Shekhar Azad University of Agriculture \& Technology, Kanpur to conduct the present study. The bio-fertilizers are used to conduct the experiment at Glass house complex of Department of Plant Pathology, C.S. Azad University of Agriculture and Technology, Kanpur during Kharif season 2016-18.

\section{Collection of Bio - agents}

Bio - agents viz., Trichoderma harzianum and Trichoderma viride of $10^{8} \mathrm{CFU}$ were collected from Department of Plant Pathology, Chandra Shekhar Azad University of Agriculture \& 
Technology, Kanpur to conduct the present investigation.

\section{Collection of seedlings}

Tomato seedling of variety Azad T-6 was obtained from Vegetable Research Farm, C.S.A. University of Agriculture \& Technology, Kanpur to conduct the experiment.

\section{Seedling treatment}

Seedling were placed in each jar containing require concentration of each solution of T.harzianum, Rhizobium and Azotobacter for two hours and are kept in shade before transplanting into the pots.

\section{Effect of IDM approach on growth parameters and disease severity of fusarium wilt in tomato}

The experiments were conducted during 20162018 at Glasshouse complex, Department of Plant Pathology, C.S.A. University of Agriculture and Technology, Kanpur. The tomato seedling of variety 'Azad T-6'was used to conduct the experiment.

The details of the treatments were given as follows:-

$\mathrm{T}_{1}=$ Soil application with mushroom spent @ $3: 1$ ratio in proportionate to soil + seedling treatment with T. harzianum @ $10^{7} \mathrm{CFU}+$ first foliar application with Benfil (Carbendazim 50\% WP) @0.1\% at $30 \mathrm{DAT}+$ second foliar application with Matco (Metalaxyl(8\%) + Mancozeb(74\%).72\%WP) @ 0.2\% at 45 days after transplanting (DAT).

$\mathrm{T}_{2}=$ Soil application with mushroom spent @ 3:1 ratio in proportionate to soil + seedling treatment with Rhizobium @ 4gm/lit water+ first foliar application with Benfil
(Carbendazim 50\% WP) @0.1\% at 30 DAT+ second foliar application with Matco (Metalaxyl (8\%)+ Mancozeb (74\%). 72\%WP) @ $0.2 \%$ at 45DAT.

$\mathrm{T}_{3}=$ Soil application with mushroom spent @ $3: 1$ ratio in proportionate to soil + seedling treatment with Azotobacter @ 4gm/lit of water+ first foliar application with Benfil (Carbendazim 50\% WP) @0.1\% at $30 \mathrm{DAT}+$ second foliar application with Matco (Metalaxyl (8\%) + Mancozeb (74\%). 72\%WP) @ $0.2 \%$ at 45DAT.

$\mathrm{T}_{4}=$ Soil application with mushroom spent @ $3: 1$ ratio in proportionate to soil + combined seedling treatment with T. harzianum @ $10^{3}$ CFU and Rhizobium@ 2gm/lit of water + first foliar application with Benfil (Carbendazim 50\% WP) @0.1\% at $30 \mathrm{DAT}+$ second foliar application with Matco (Metalaxyl(8\%)+ Mancozeb(74\%).72\%WP) @ $0.2 \%$ at 45DAT.

$\mathrm{T}_{5}=$ Soil application with mushroom spent @ 3:1 ratio in proportionate to soil + combined seedling treatment with Rhizobium @ 2gm/lit water and Azotobacter@2gm/lit of water+ first foliar application with Benfil (Carbendazim $50 \%$ WP) @0.1\% at $30 \mathrm{DAT}+$ second foliar application with Matco (Metalaxyl(8\%)+ Mancozeb(74\%).72\%WP) @ 0.2\% at 45DAT.

$\mathrm{T}_{6}=$ Soil application with mushroom spent @ $3: 1$ ratio in proportionate to soil + combined seedling treatment with T. harzianum @ 10 ${ }^{3}$ CFU and Azotobacter @ 2gm/lit of water + first foliar application with Benfil (Carbendazim 50\% WP) @ 0.1\% at 30 DAT+ second foliar application with Matco (Metalaxyl(8\%)+ Mancozeb (74\%).72\%WP) @ $0.2 \%$ at $45 \mathrm{DAT}$.

$\mathrm{T}_{7}=$ Soil application with mushroom spent @ $3: 1$ ratio in proportionate to soil + combined seedling treatment with T. harzianum @10 $0^{3}$ CFU and Azotobacter@2gm/lit of water and 
Rhizobium@2gm/lit of water + first foliar application with Benfil (Carbendazim 50\% WP) @0.1\% at 30 DAT+ second foliar application with Matco (Metalaxyl (8\%) + Mancozeb (74\%). 72\%WP) @ $0.2 \%$ at 45DAT.

$\mathrm{T}_{8}=$ Soil application with of mushroom spent @ 250gm/pot.

$\mathrm{T}_{9}=$ Soil application with mushroom spent @ $250 \mathrm{gm} / \mathrm{pot}+$ inoculation with pathogen.

At 28 DAT plants were inoculated with spore suspension of $F$. o. f sp. lycopersicae @ $10^{6}$ conidia/ml. Four replications per treatment were kept to conduct the experiment.

Observations pertaining to the effect of different treatments were recorded as per following parameters and days.

Plant height $(\mathrm{cm})$ at 30, 45 and 60 days after transplanting.

Fresh weight of shoot (g) at 45 days after transplanting.

Dry weight of shoot (g) at 45 days after transplanting.

Root length $(\mathrm{cm})$ and morphology at 45 days after transplanting

Fresh weight of root (g) at 45 days after transplanting

Dry root weight (g) at 45 days after transplanting.

Average number of branches per plant at 45 days

Disease severity (\%) at 45 days after transplanting

Fruiting parameters and yield of crop (g)

\section{Growth parameters}

\section{Shoot length}

Tomato seedlings were transplanted in earthen pots in the glasshouse and shoot length was measured 30, 45 and 60 days age of tomato plants with the help of scale.

\section{Root length}

The root length tomato was measure at 45 days age of plant. Prior to measure the root lengths of tomato plants, pots were irrigated and the seedlings were up rooted carefully, roots of seedlings were separated from the shoots and washed with water to remove soil particles and then root length $(\mathrm{cm})$ were measured with the help of scale.

\section{Fresh weight}

Forty five days after transplanting, the shoots and roots of tomato plant were weighted on an electronic balance and the data was recorded as gm.

\section{Dry weight}

The fresh plant sample of 45 days age of plants is being collected and then shoots and roots were dried in an oven at $70^{\circ} \mathrm{C}$ until constant weight.

It was then weighted on an electronic balance and the data was recorded as gm.

\section{Measurement of disease severity}

The disease severity was monitored visually after inoculation with pathogen. The disease severity was recorded using 0-4 scale (Weitang et al., 2004) where zero representing no infection and four denoting plants completely infected. The 0-4 scale of the disease Incidence was classified as follows:- 
No infection

Slight infection which is about $25 \%$ of full scale, one or two leaves become yellow.

Moderate infection, two or three leaves become yellow, $50 \%$ of leaves become wilted

Extensive infection, all plant leaves become yellow, $75 \%$ of leaves become wilted, and the plants die.

Complete infection, the whole plant leaves become yellow, $100 \%$ of leaves become wilted and the plants die.

The percentage of disease incidence was determined using the formula:-

Disease incidence

$=\frac{(\text { ScaleXnumberof plantsinf fected) }}{(\text { highestscale } \times \text { Totalnumberof Plants })} \times 100$

\section{Yield/plant}

The edible fruits were harvested twice a week from each selected plant and weighted with the help of physical balance and graded as per weight.

The total weight of all picking was recorded after adding weight of fruits at each picking and represented as gm.

\section{Results and Discussion}

Seven various effective management components using seedling treatments $(T$. harzianum, Azotobacter and Rhizobium), soil treatments (Mushroom spent) and Foliar applications (Carbendazim 50\% WP, (Metalaxyl(8\%)+ Mancozeb(74\%). 72\%WP) were used to suppress the population of wilt causing pathogen (Fusarium oxyporium f.sp. lycopersici) in tomato and their effects on shoot length $(\mathrm{cm})$, root length $(\mathrm{cm})$, fresh and dry weight of shoot (gm), fresh and dry weight of root (gm), disease severity (\%), flowering, branching and yield of tomato.

Effect of different IDM practices on growth parameters and disease severity of Fusarium wilt of tomato

\section{Shoot length}

The data presented in the Table 1, showed that all the treatments were able to significantly increase the shoot length over both the controls at 30, 45, 60 days after transplanting. Among the various IDM practices, the maximum shoot length was recorded in the treatment $\mathrm{T}_{7}$ (Soil application with mushroom spent + combined seedling treatment with $T$. harzianum, Azotobacter and Rhizobium + two foliar sprays with Benfil (Carbendazim) and Matco (Metalaxy+ Mancozeb) representing $28.90,45.50$ and $57.90 \mathrm{~cm}$ at 30,45 and 60 days after transplanting, followed by $\mathrm{T}_{6}$ treatment (Soil application with mushroom spent + combined seedling treatment with $T$. harzianum and Azotobacter + two foliar spray with Carbendazim and Metalaxy+ Mancozeb) showing 26.50, 42.10 and $54.70 \mathrm{~cm}$ against control-1 (healthy) representing as 17.50, $29.50,36.40 \mathrm{~cm}$ and control-2 (diseased) as $14.30,23.40$ and $30.20 \mathrm{~cm}$ at 30,45 and 60 days after transplanting.

Ravindra et al., (2015) also found that seed treatment with $T$. harzianum + soil application of neem cake powder + foliar spray of carbendazim significantly increased shoot and root lengths of tomato. Yogesh et al., (2015) also reported that among the different integrated approaches, soil application of FYM + seedling treatment with bioformulation of Trichoderma harzianum + foliar spray of mancozeb reduced the disease severity of early blight of tomato and increased the growth parameters and branching pattern of plant. 


\section{Fresh and dry weight of Shoot}

Fresh and dry shoots were weighted on an electronic balance and the data presented in the Table 1, showed that all the treatments were able to increase the fresh and dry weights of shoots over control-1 and control-2. The maximum fresh and dry weight of shoots was recorded in $\mathrm{T}_{7}$ treatment where treatment was given as soil application with mushroom spent + combined seedling treatment with $T$. harzianum, Azotobacter and Rhizobium + two foliar sprays with Benfil (Carbendazim) and Matco (Metalaxy+ Mancozeb) representing $66.50 \mathrm{gm}$ and $21.50 \mathrm{gm}$ respectively, at 45 days after transplanting, which is increased by $92.75 \& 146.30$ and $91.96 \& 123.70$ per cent over contol-1 (Healthy) and control-2 (Diseased plant), respectively. The $\mathrm{T}_{6}$ treatment (Soil application with mushroom spent + combined seedling treatment with $T$. harzianum and Azotobacter + foliar spray with Benfil (Carbendazim) and with Matco (Metalaxyl+ Mancozeb) showing the values $63.15 \mathrm{gm}$ and $19.00 \mathrm{gm}$ at 45 days after transplanting representing second highest among the treatments.

Among the all combinations, the minimum fresh and dry weight was recorded in $\mathrm{T}_{2}$ (Soil application with mushroom spent +seedling treatment with Rhizobium + two foliar spray with Benfil (Carbendazim) and with Matco (Metalaxy+ Mancozeb) treatment, representing 48.60 and $12.70 \mathrm{gm}$ which are also superior as 40.865 and 13.40 and 80.00 and 32.3 per cent increased over control- 1 and control-2.Tippannaves et al., (2005) had observed that the Azotobactor significantly increase the tillering, drymatter accumulation and growth parameter. Ravindra et al., (2015) found that the fresh and dry weight of shoot in tomato crop significantly increased by the combine application of seed treatment with $T$. harzianum + soil application of neem cake powder + foliar spray of Carbendazim.

\section{Root length}

Forty five days after transplanting, the tomato plant was uprooted and the root length was measured by using scale. It is evident from the data showed that the maximum root length was recorded in the treatment $T_{7}$ where the treatment was given as soil application with mushroom spent + combined seedling treatment with $T$. harzianum, Azotobacter and Rhizobium + two foliar sprays with Benfil (Carbendazim) and Matco (Metalaxy+ Mancozeb) representing $37.00 \mathrm{~cm}$ against 10.15 and $8.5 \mathrm{~cm}$ in case of control-1 and control-2, respectively at 45 days after transplanting (Table 2) which was followed by the $\mathrm{T}_{6}$ treatment (Soil application with mushroom spent + combined seedling treatment with T. harzianum and Azotobacter + two foliar sprays with Benfil (Carbendazim) and Matco (Metalaxy+ Mancozeb), representing $29.00 \mathrm{~cm}$ at 45 days after transplanting. The morphology of the roots was also found variable among different treatments. Among the various combinations, robust spreading root system was found maximum in T7 treatment. From the table, it is cleared that all the treatments are able to increase the root length over control which are also statistically significant to each other. Kishan et al., (2015) found that integrated approaches changes the morphology of root.

The well-developed robust root system is found in combine treatment withsoil application of FYM @ 100gm/pot+ Neem cake@100gm/pot + seedling treatment with bio-formulation of Azotobactor @ 5\%+foliar spray of Carbendazim@0.1\%) whereas, in case of control, poorly developed, less branching and less fibrous root system are found. Gopinathan and Prakesh (2014) found that vermicompost enriched with bio-fertilizer increased plant height, root length, number of branches, number of leaves and the productivity of tomato. 
Table.1 Effect of different IDM practices on Shoot length at different days after transplanting and disease severity of Fusarium wilt of tomato

\begin{tabular}{|c|c|c|c|c|c|c|c|c|c|c|c|}
\hline \multirow{2}{*}{$\begin{array}{l}\text { S. } \\
\text { No. }\end{array}$} & \multirow[t]{2}{*}{ Treatment } & \multicolumn{3}{|c|}{ Shoot length } & \multirow{2}{*}{$\begin{array}{l}\text { Fresh } \\
\text { weight } \\
\text { of shoot } \\
\text { (gm) }\end{array}$} & \multirow[b]{2}{*}{$\begin{array}{l}\% \\
\text { increase } \\
\text { of fresh } \\
\text { weight } \\
\text { over } \\
\text { control -1 }\end{array}$} & \multirow[b]{2}{*}{$\begin{array}{l}\% \\
\text { increase } \\
\text { of fresh } \\
\text { weight } \\
\text { over } \\
\text { control-2 }\end{array}$} & \multirow[b]{2}{*}{$\begin{array}{l}\text { Dry } \\
\text { weight } \\
\text { of } \\
\text { shoot } \\
\text { (gm) }\end{array}$} & \multirow[b]{2}{*}{$\begin{array}{l}\% \\
\text { increase } \\
\text { of dry } \\
\text { weight of } \\
\text { shoot } \\
\text { over } \\
\text { control } 1\end{array}$} & \multirow[b]{2}{*}{$\begin{array}{l}\% \\
\text { increase } \\
\text { of dry } \\
\text { weight of } \\
\text { shoot over } \\
\text { control -2 }\end{array}$} & \multirow{2}{*}{$\begin{array}{l}\text { Disease } \\
\text { severity } \\
(\%) \\
\text { 45 DAT }\end{array}$} \\
\hline & & $\begin{array}{l}30 \\
\text { DAT }\end{array}$ & $\begin{array}{l}45 \\
\text { DAT }\end{array}$ & $\begin{array}{l}60 \\
\text { DAT }\end{array}$ & & & & & & & \\
\hline 1. & $\begin{array}{l}\text { T}_{1} \text { - SA with MS }+\mathrm{ST} \text { with } T \text {. harzianum }+1^{\text {st }} \mathrm{FA} \\
\text { with Carbendazim }+2^{\text {nd }} \text { FA with Metalaxy+ } \\
\text { Mancozeb }\end{array}$ & 22.00 & 37.60 & 47.60 & 57.30 & 66.08 & 112.20 & 15.30 & 36.60 & 59.40 & 14.55 \\
\hline 2. & $\begin{array}{l}\mathbf{T}_{2^{-}} \text {SA with MS }+\mathrm{ST} \text { with Rhizobium }+1^{\text {st }} \text { FA with } \\
\text { Carbendazim }+2^{\text {nd }} \text { FA with Metalaxy+ Mancozeb. }\end{array}$ & 19.60 & 34.30 & 43.50 & 48.60 & 40.86 & 80.00 & 12.70 & 13.40 & 32.30 & 19.20 \\
\hline 3. & $\begin{array}{l}\mathbf{T}_{3^{-}} \text {SA with MS }+\mathrm{ST} \text { with Azotobacter }+1^{\text {st }} \mathrm{FA} \text { with } \\
\text { Carbendazim }+2^{\text {nd }} \text { FA with Metalaxy+ Mancozeb }\end{array}$ & 20.40 & 32.40 & 44.80 & 52.40 & 51.88 & 94.10 & 13.60 & 21.42 & 41.70 & 17.30 \\
\hline 4. & $\begin{array}{l}\mathbf{T}_{4} \text { - SA with MS }+ \text { ST with } T \text {. harzianum }+ \text { Rhizobium } \\
+1^{\text {st }} \text { FA with Carbendazim }+2^{\text {nd }} F A \text { with Metalaxy }+ \\
\text { Mancozeb }\end{array}$ & 25.20 & 40.80 & 53.10 & 61.80 & 79.13 & 128.80 & 17.50 & 56.25 & 82.30 & 9.40 \\
\hline 5. & $\begin{array}{l}\mathbf{T}_{\mathbf{5}} \text {-SA with } \mathrm{MS}+\mathrm{ST} \text { with Rhizobium and } \\
\text { Azotobacter }+1^{\text {st }} \text { FA with Carbendazim }+2^{\text {nd }} \text { FA with } \\
\text { Metalaxy+ Mancozeb }\end{array}$ & 23.70 & 39.20 & 50.30 & 60.10 & 74.20 & 122.60 & 16.30 & 45.53 & 69.80 & 11.70 \\
\hline$\overline{6 .}$ & $\begin{array}{l}\text { T. }_{\text {- }} \text { SA with MS+ ST with } T \text {. harzianum and } \\
\text { Azotobacter }+1^{\text {st }} \text { FA with Carbendazimand } 2^{\text {nd }} \text { FA } \\
\text { with Metalaxy+ Mancozeb }\end{array}$ & 26.50 & 42.10 & 54.70 & 63.15 & 83.04 & 133.90 & 19.00 & 69.64 & 97.90 & 7.25 \\
\hline 7. & $\begin{array}{l}\text { T }_{7} \text { SA with MS }+ \text { ST with } T \text {. harzianum, Azotobacter } \\
\text { and Rhizobium }+1^{\text {st }} \text { FA with Carbendazim }+2^{\text {nd }} \text { FA } \\
\text { with Metalaxy+ Mancozeb }\end{array}$ & 28.90 & 45.50 & 57.90 & 66.50 & 92.75 & 146.30 & 21.50 & 91.96 & 123.90 & 6.50 \\
\hline 8. & $\mathbf{T}_{\mathbf{8}}$ Control(Healthy)- Soil application with of MS & 17.50 & 29.50 & 36.40 & 34.50 & & 27.70 & 11.20 & & 16.70 & 0 \\
\hline 9. & $\begin{array}{l}\text { T9 Control(diseased)- Soil application with of } \\
\text { MS+inoculation with pathogen }\end{array}$ & 14.30 & 23.40 & 30.20 & 27.00 & -21.73 & & 9.60 & -14.28 & & 54.65 \\
\hline 10. & C.D. & 1.294 & 1.164 & 1.164 & 1.450 & & & 1.422 & & & 1.199 \\
\hline 11. & $\mathrm{SE}(\mathrm{m})$ & 0.432 & 0.389 & 0.389 & 0.484 & & & 0.475 & & & 0.401 \\
\hline 12. & $\mathrm{SE}(\mathrm{d})$ & 0.611 & 0.550 & 0.550 & 0.685 & & & 0.672 & & & 0.567 \\
\hline 13. & C.V. & 3.400 & 1.866 & 1.448 & 1.601 & & & 5.416 & & & 4.443 \\
\hline
\end{tabular}

SA = Soil Application, MS = Mushroom Spent, ST = Seedling Treatment, FA = Foliar Application. 
Table.2 Effect of different IDM practices on growth characteristics of roots of tomato at 45 days after transplanting

\begin{tabular}{|c|c|c|c|c|c|c|c|c|c|c|}
\hline $\begin{array}{l}\text { S. } \\
\text { No. }\end{array}$ & Treatment & $\begin{array}{l}\text { Root } \\
\text { length } \\
(\mathrm{cm})\end{array}$ & $\begin{array}{l}\% \\
\text { increase } \\
\text { of root } \\
\text { length } \\
\text { over } \\
\text { control-1 }\end{array}$ & $\begin{array}{l}\% \\
\text { increase of } \\
\text { root length } \\
\text { over } \\
\text { control-2 }\end{array}$ & $\begin{array}{l}\text { Fresh } \\
\text { weight } \\
\text { of root } \\
\text { (gm) }\end{array}$ & $\begin{array}{l}\% \text { increase } \\
\text { of fresh } \\
\text { weight of } \\
\text { root over } \\
\text { control-1 }\end{array}$ & $\begin{array}{l}\text { \% increase } \\
\text { of fresh } \\
\text { weight of } \\
\text { root over } \\
\text { control- } 2\end{array}$ & $\begin{array}{l}\text { Dry } \\
\text { weight } \\
\text { of root } \\
(\mathrm{gm})\end{array}$ & $\begin{array}{l}\% \\
\text { increase } \\
\text { of dry } \\
\text { weight of } \\
\text { root over } \\
\text { control-1 }\end{array}$ & $\begin{array}{l}\% \\
\text { increase } \\
\text { of dry } \\
\text { weight of } \\
\text { root over } \\
\text { control-2 }\end{array}$ \\
\hline 1. & $\begin{array}{l}\mathrm{T}_{1}-\mathrm{SA} \text { with } \mathrm{MS}+\mathrm{ST} \text { with } T \text {. harzianum }+1^{\text {st }} \mathrm{FA} \\
\text { with Carbendazim }+2^{\text {nd }} \mathrm{FA} \text { with Metalaxy+ } \\
\text { Mancozeb }\end{array}$ & 23.20 & 128.50 & 172.90 & 26.50 & 55.90 & 89.30 & 7.85 & 86.90 & 101.20 \\
\hline 2. & $\begin{array}{l}\mathrm{T}_{2} \text {-SA with MS }+\mathrm{ST} \text { with Rhizobium }+1^{\text {st }} \mathrm{FA} \text { with } \\
\text { Carbendazim }+2^{\text {nd }} \text { FA with Metalaxy }+ \text { Mancozeb. }\end{array}$ & 20.50 & 101.90 & 141.20 & 23.00 & 35.30 & 64.30 & 5.70 & 35.70 & 46.10 \\
\hline 3. & $\begin{array}{l}\mathrm{T}_{3} \text {-SA with MS }+\mathrm{ST} \text { with Azotobacter }+1^{\text {st }} \mathrm{FA} \text { with } \\
\text { Carbendazim }+2^{\text {nd }} \mathrm{FA} \text { with Metalaxy+ Mancozeb }\end{array}$ & 22.00 & 116.70 & 158.80 & 24.50 & 44.20 & 75.00 & 6.55 & 55.90 & 67.90 \\
\hline 4. & $\begin{array}{l}\mathrm{T}_{4} \text {-SA with } \mathrm{MS}+\mathrm{ST} \text { with } T . \text { harzianum } \\
+ \text { Rhizobium }+1^{\text {st }} \text { FA with Carbendazim }+2^{\text {nd }} \text { FA } \\
\text { with Metalaxy }+ \text { Mancozeb }\end{array}$ & 27.00 & 166.00 & 217.60 & 29.00 & 70.60 & 107.10 & 9.95 & 136.90 & 155.10 \\
\hline 5. & $\begin{array}{llrr}\mathrm{T}_{5}-\mathrm{SA} \text { with } \quad \mathrm{MS} & +\mathrm{ST} & \text { with } \\
\text { RhizobiumandAzotobacter }+1^{\text {st }} & \text { FA } & \text { with } \\
\text { Carbendazim }+2^{\text {nd }} \text { FA with Metalaxy } & \text { Mancozeb }\end{array}$ & 25.5 & 151.20 & 200.00 & 27.50 & 61.80 & 96.40 & 8.35 & 98.80 & 114.10 \\
\hline 6. & $\begin{array}{l}\mathrm{T}_{6}-\mathrm{SA} \text { with } \mathrm{MS}+\mathrm{ST} \text { with } T \text {. harzianum and } \\
\text { Azotobacter }+1^{\text {st }} \text { FA with Carbendazimand } 2^{\text {nd }} \text { FA } \\
\text { with Metalaxy }+ \text { Mancozeb }\end{array}$ & 29.00 & 185.70 & 241.20 & 33.00 & 94.10 & 135.70 & 10.25 & 144.00 & 162.80 \\
\hline 7. & $\begin{array}{l}\mathrm{T}_{7} \text {-SA with MS+ ST with } T . \text { harzianum, } \\
\text { Azotobacter and Rhizobium }+1^{\text {st }} \text { FA with } \\
\text { Carbendazim }+2^{\text {nd }} \text { FA with Metalaxy+ Mancozeb }\end{array}$ & 37.00 & 264.50 & 335.20 & 36.50 & 114.70 & 160.70 & 12.30 & 192.80 & 215.30 \\
\hline 8. & $\mathrm{~T}_{8^{-}}$Control-1(Healthy)-Soil application with of MS & 10.15 & & 19.41 & 17.00 & & 21.40 & 4.20 & & 7.70 \\
\hline 9. & $\begin{array}{l}\mathrm{T}_{9} \text {-Control-2(diseased)-Soil application with of } \\
\text { MS+inoculation with pathogen }\end{array}$ & 8.50 & -16.25 & & 14.00 & -17.64 & & 3.90 & -7.10 & \\
\hline 10. & C.D. & 1.934 & & & 2.445 & & & 1.006 & & \\
\hline 11. & $\mathrm{SE}(\mathrm{m})$ & 0.646 & & & 0.816 & & & 0.336 & & \\
\hline 12. & $\mathrm{SE}(\mathrm{d})$ & 0.914 & & & 1.155 & & & 0.475 & & \\
\hline 13. & C.V. & 4.956 & & & 5.510 & & & 7.581 & & \\
\hline
\end{tabular}

SA $=$ Soil Application, MS = Mushroom Spent, ST $=$ Seedling Treatment, FA = Foliar Application . 
Table.3 Effect of various IDM practices on yield attributing characters and yield of tomato

\begin{tabular}{|c|c|c|c|c|c|c|c|c|c|c|}
\hline \multirow{2}{*}{$\begin{array}{l}\text { S. } \\
\text { No. }\end{array}$} & \multirow[t]{2}{*}{ Treatment } & \multirow{2}{*}{$\begin{array}{l}\text { No of } \\
\text { branches }\end{array}$} & \multirow{2}{*}{$\begin{array}{l}\text { No of } \\
\text { flowers } \\
\text { /plant }\end{array}$} & \multicolumn{3}{|c|}{ No of fruits/plant } & \multicolumn{3}{|c|}{ Wt of fruits } & \multirow{2}{*}{$\begin{array}{l}\text { Total } \\
\text { yield( } \\
\text { gm) }\end{array}$} \\
\hline & & & & $<25 \mathrm{gm}$ & 25-50gm & $>50 \mathrm{gm}$ & $<25 \mathrm{gm}$ & $25-50 \mathrm{gm}$ & $>50 \mathrm{gm}$ & \\
\hline 1. & $\begin{array}{l}\mathrm{T}_{1^{-}} \mathrm{SA} \text { with } \mathrm{MS}+\mathrm{ST} \text { with } T \text {. harzianum }+1^{\text {st }} \text { FA with } \\
\text { Carbendazim }+2^{\text {nd }} \text { FA with Metalaxy+ Mancozeb }\end{array}$ & 8.00 & 71.30 & 5 & 12 & 12 & 95 & 468 & 612 & 1175 \\
\hline 2. & $\begin{array}{l}\mathrm{T}_{2^{-}} \mathrm{SA} \text { with } \mathrm{MS}+\mathrm{ST} \text { with Rhizobium+ } 1^{\text {st }} \text { FA with } \\
\text { Carbendazim }+2^{\text {nd }} \text { FA with Metalaxy+ Mancozeb. }\end{array}$ & 6.20 & 64.50 & 7 & 10 & 8 & 147 & 360 & 424 & 931 \\
\hline 3. & $\begin{array}{l}\mathrm{T}_{3^{-}} \mathrm{SA} \text { with } \mathrm{MS}+\mathrm{ST} \text { with Azotobacter+ } 1^{\text {st }} \text { FA with } \\
\text { Carbendazim }+2^{\text {nd }} \text { FA with Metalaxy+Mancozeb }\end{array}$ & 7.40 & 68.20 & 6 & 13 & 9 & 102 & 442 & 486 & 1030 \\
\hline 4. & $\begin{array}{l}\mathrm{T}_{4}-\mathrm{SA} \text { with } \mathrm{MS}+\mathrm{ST} \text { with } T \text {. harzianum }+ \text { Rhizobium }+1^{\text {st }} \mathrm{FA} \\
\text { with Carbendazim }+2^{\text {nd }} \text { FA with Metalaxy }+ \text { Mancozeb }\end{array}$ & 10.30 & 77.50 & 6 & 14 & 14 & 114 & 518 & 742 & 1374 \\
\hline 5. & $\begin{array}{l}\mathrm{T}_{5} \text {-SA with } \mathrm{MS}+\mathrm{ST} \text { with RhizobiumandAzotobacter }+1^{\text {st }} \mathrm{FA} \\
\text { with Carbendazim }+2^{\text {nd }} \text { FA with Metalaxy }+ \text { Mancozeb }\end{array}$ & 9.60 & 73.80 & 7 & 15 & 12 & 133 & 554 & 624 & 1311 \\
\hline 6. & $\begin{array}{l}\mathrm{T}_{6}-\mathrm{SA} \text { with MS+ ST with } T \text {. harzianum and Azotobacter }+1^{\text {st }} \\
\text { FA with Carbendazimand } 2{ }^{\text {nd }} \text { FA with Metalaxy+ Mancozeb }\end{array}$ & 12.40 & 82.00 & 6 & 17 & 15 & 108 & 629 & 810 & 1547 \\
\hline 7. & $\begin{array}{l}\mathrm{T}_{7} \text {-SA with MS+ ST with T. harzianum, Azotobacter and } \\
\text { Rhizobium }+1^{\text {st }} \text { FA with Carbendazim }+2^{\text {nd }} \text { FA with Metalaxy+ } \\
\text { Mancozeb }\end{array}$ & 13.60 & 90.60 & 8 & 16 & 18 & 144 & 592 & 972 & 1703 \\
\hline 8. & $\mathrm{~T}_{8}$ Control(Healthy)- Soil application with of MS & 5.80 & 50.90 & 9 & 7 & 5 & 198 & 252 & 280 & 730 \\
\hline 9. & $\begin{array}{l}\mathrm{T}_{9} \text { Control(diseased)- Soil application with of MS+inoculation } \\
\text { with pathogen }\end{array}$ & 3.60 & 16.40 & 4 & 2 & 1 & 86 & 37 & 51 & 174 \\
\hline 10. & C.D. & 1.309 & 2.309 & & & & & & & 0.069 \\
\hline 11. & $\mathrm{SE}(\mathrm{m})$ & 0.437 & 0.771 & & & & & & & 0.023 \\
\hline 12. & $\mathrm{SE}(\mathrm{d})$ & 0.618 & 1.090 & & & & & & & 0.033 \\
\hline 13. & C.V. & 8.862 & 2.019 & & & & & & & 3.611 \\
\hline
\end{tabular}

SA = Soil Application, MS = Mushroom Spent, ST = Seedling Treatment, FA = Foliar Application. 


\section{Fresh and dry weight of root}

Fresh and dry roots were weighted on an electronic balance and the data presented in the Table 2, showed that all the treatments were able to increase the fresh and dry weights of roots over control-1 and control-2. The maximum fresh and dryweight of root was recorded in $\mathrm{T}_{7}$ treatment (Soil application with mushroom spent + combined seedling treatment with $T$. harzianum, Azotobacter and Rhizobium+ two foliar sprays with Benfil (Carbendazim) and Matco (Metalaxy+ Mancozeb) representing 36.50 and $12.30 \mathrm{gm}$ at 45 days after transplanting which is increased 114.7 and 192.80 per cent over control-1 and 160.70 and 215.00 per cent over control-2. Similar observations have also been reported by several workers (Yogesh et al., 2015, Singh et. al. 2016, Ravindra, et al., 2015)

\section{Disease Severity}

Disease is major constraints of increase production and productivity of any crops. In contrast, adoption of suitable management practices is more important to reduce disease severity and to get maximum profit. In the present study also, among the various IDM packages maximum reduction of disease severity was found in treatment $T_{7}$ where treatments were given as soil application with mushroom spent + combined seedling treatment with $T$. harzianum, Azotobacter and Rhizobium+ two foliar sprays with Benfil (Carbendazim) and Matco (Metalaxy + Mancozeb) representing only $6.50 \%$ disease severity against $54.65 \%$ in case of control. Effectiveness of mushroom composts use as soil amendments in controlling the disease could possibly be due to enhanced activity of other non-parasitic microbes (fungi/bacteria) providing antagonism to the tomato wilt pathogen and/or decomposition products of composts being non- favourable for the multiplication of the inoculum. Christopher et al., (2010) has been found that seed plus soil application of $T$. harzianum along with organic amendments reduced wilt incidence and increased the fruit yield of tomato. Biological control integrated with fungicidal treatment has also been found more reliable approach to manage soil borne plant pathogen was reported by Mukhopadhyay (1987). Ganie et al., (2013) observed that the application of bio-agents viz., T.viridae and Azotobacter is effective in reducing disease severity of Fusarium wilt in tomato caused by F. o. f.sp. lycopersici.

\section{Effect of IDM practices on yield attributing characters and yield of tomato}

Yield attributing characters like number of branches, flowers and fruit yield have been gradually increased in the treated plants (Table 3) where the maximum number of branches and flowers were produced in treatment $\mathrm{T}_{7}$ with 13.60 branches/plant and 90.60 flowers/plant, respectively followed by treatment $\mathrm{T}_{6}$ with 12.04 branches/plant and 82 flowers /plant. The matured fruits were harvested and were graded according to the weight viz., (<25gm, 25-50gm and >50gm) using physical balance. It was found that the maximum number of large size fruits with 18 was obtained from $\mathrm{T}_{7}$ Treatment(Soil application with mushroom spent + combined seedling treatment with $T$. harzianum, Azotobacter and Rhizobium + two foliar sprays with Benfil (Carbendazim) which is also representing hinghest yield as $1.703 \mathrm{~kg}$ per plant which was followed by $\mathrm{T}_{6}$ treatment (Soil application with mushroom spent + combined seedling treatment with $T$. harzianum and Azotobacter + two foliar spray with Benfil (Carbendazim) and Matco (Metalaxy + Mancozeb) as 15 large size fruits and total yield $1.547 \mathrm{~kg}$ per plant. In case of control-1 and control-2, the number of large size fruits are 5 and 1 , respectively and their 
yield as 730 and 174 gm per plant. The maximum number of small size and medium size fruits was obtained from $\mathrm{T}_{8}$ and $\mathrm{T}_{6}$ treatments, respectively. From the Table 3 it is also cleared that the increase number of fruiting ability are found in $\mathrm{T}_{7}$ treatment which is 42 against 7 in case of control-2. The reduction in wilt incidence mediated through bio agents in combination with organic amendments, was found to have direct effect on improving yield attributing characters (number of branches, flowers, plant height etc.) leading to increase in yield reported by Pandey et al., (2005). Jayaraj and Ramabadran (1999) also reported that increase in the yield and total biomass was due to occasional synergism of Rhizobium + Trichoderma in black gram. Ravindra (2015) found that the yield of tomato crop significantly increased by the combine application of seed treatment with $T$. harzianum + soil application of neem cake powder + foliar spray of carbendazim.

\section{References}

Beckman, C.H. (1987). The nature of wilt diseases of plants. The American Phytopathological Society. St. Paul. $174 p p$

Bhatnagar, K., Tak, S.K., Sharma, R.S., Majumdar, V.L. and Meena, R.L. (2013). Management of cumin wilt caused by Fusarium oxysporum f. sp. cumini through chemical and biological agents. Indian Phytopath., 66(1): 101102.

Bhupendra, Vinit pratapsingh, Swetasrivastav, Abhay kumarpandey and Shukla, D.N. (2017). Influence of soil properties on wilt Incidence of water melon, tomato and marigold. Annual Research \& Review in Biology, 19(5): 1-6.

Christopher, D.J., Raj, T.S., Shanmugapackiam, S., Udhayakumar, and Dayaram, P. (1997). Fungitoxicity of some plant extracts against Alternaria brassica. Annal. Agric. Bio. Res., 2: 25-26.

Duffy, B.K. and G. Défago, (1997). Zinc improves biocontrol of Fusarium crown and root rot of tomato by Pseudomonas fluorescens and represses the production of pathogen metabolites inhibitory to bacterial antibiotic biosynthesis. Phytopathology, 87: 1250-57.

Ganie, S.A., Ghani, M.Y., Qazi Nissar and Shabir-Rehman. (2013). Bioefficacy of plant extract and biocontrol agents against Fusarium wilt of tomato. African journal of microbiology Research, 7(34): 4397-4402.

Gill, H.K., Aujla, I.S., De Bellis, L. and Luvisi, A. (2016). The role of soil solarization in India: How an unnoticed practice could support pest control. Front. Plant Sci., 8: 1515.

Gopinathan and Prakash (2014) Effect of vermicompost enriched with biofertilizers on the productivity of tomato (Lycopersicum esculentum Mill.). International J. of Current Microbiology and Applied Sciences, 3(9): 1238-1245

Hanaa, R.M.F., Abdou, Z.A., Salama, D.A., Ibrahim, M.A.R. and Sror, H.A.M. (2011). Effect of neem and willow aqueous extracts on fusarium wilt disease in tomato seedlings: induction of antioxidant defensive enzymes. Ann Agric Sci., 56: 1-7.

Jayaraj, J. And Ramabadran, R. (1999). Rhizobium - Trichoderma interaction in vitro and in vivo. Indian Phytopath., 52(2): 190-192.

Kapsiya, J. Gungula, D.T., Tame, V.T., Bukar, N. (2015). Effects of storage chemicals and packaging systems on physicochemical characteristics of tomato (Solanum lycopersicum L.) fruits. AASCIT J Biosci, 1: 41-46. 
Kishan Lal, Pappu Singh, S. K. Biswas, Supriya Yadav, Virendra Kumar and Narender Kumar (2017). Suitable Integrated Approach for Management of Fusarium Wilt of Tomato caused by Fusarium oxysporum f. sp. lycopersici (Sacc.). J. of Pure Appl. Microbiol, 11(2): 953-961

Minuto, A., Gilardi, G., Gullino, M.L. and Garibaldi, A. (2000). Combination of soil solarization and Dazomet against soil borne pathogens of glasshousegrown basil, tomato and lettuce. Acta Hort., 532: 165-170.

Mukhopadhyay, A.N. (1987). Biological control of soil borne plant pathogens by Trichoderma spp. J. Mycol. Pl. Pathol., 17: 1-9.

Narender, K. Bharat and Jitender Sharma. (2015). Management of Fusarium wilt of tomato under protected conditions using Brassica crop residues, AM fungi and biocontrol agents. Indian Phytopath., 68(3): 287-292.

Pandey, K.K. and Pandey, P.K. (2005). Differential response of biocontrol agents against soil pathogens on tomato, chilli and brinjal. Indian Phytopath., 58(3): 329-331.

Ravindra Singh, Biswas, S.K., Nagar Devesh, Singh Jskaran, Singh, Morajdhwaj and Mishra yogesh Kumar (2015). Sustainable integrated approach for management of fusarium wilt of tomato caused by Fusarium oxysporum f.sp. lycopersici (Sacc.) Snyder and Hansen. Sustainable Agriculture Research, 4(1): 138-147.
Sharma, R.D. and Cerauskar, R.F. (1985). Interaction between Meloidogyne javanica and Fusarium oxysporum f. sp. ciceri on chick pea. Nematologi Brasilieria, 9: 113-121.

Singh, Morajdhwaj, Biswas, S.K., Kishan Lal, Devesh Nagar, Jaskaran Singh and Prem Naresh (2016). Development of suitable package using bio-fertilizers for management of late blight of potato under climate change. J. Pure and Appl. Microbiol. 10(1): $761-768$.

Singh, R.S. (2014). Plant Diseases $9^{\text {th }}$ edition. ISBN978-81-204-17465.

Sivan, A. and Chet, I. (1993). Integrated control of Fusarium crown and root rot of tomato with Trichoderma harzianum in combination with methyl bromide or soil sterilization. Crop Protection, 12: 380-386.

Tippannavar, C.M., Kutkaeni, J.B. and Reddy, R. (2005). Toxicity of wheat seed diffusates on the growth of seed bornAzotobacter isolate. Crop Research Hisar, 25 (2): 337-340.

Weitang, S., Ligang, Z., Chengzong, Y., Xiaodong, C., Liqun, Z. \&Xili, L. (2004). Tomato Fusarium wilt and its chemical control strategies in a hydroponic system. Crop protection, 22(3): 120-123.

Yogesh M., Biswas, S. K., Lal, K., Naresh, P., Sushree, A. and Kumar, N. Sustainable integrated approach for management of early blight and their effect on crop growth parameters in tomato. The Bioscan, 2015; 11(1):133-139.

\section{How to cite this article:}

Vallabhaneni Tilak Chowdary, S.K. Biswas, Deepak Baboo and Sumit Kumar. 2018. Development of Suitable IDM Approaches for Management of Fusarium Wilt of Tomato [Fusarium oxysporum f.sp. lycopersici (Sacc.) Synder and Hansen] under Climate Change. Int.J.Curr.Microbiol.App.Sci. 7(11): 2090-2101. doi: https://doi.org/10.20546/ijcmas.2018.711.235 